\title{
Cover Crop Rotation Effects on Growth and Development, Seedling Disease, and Yield of Corn and Soybean
}

\author{
Jyotsna Acharya, ${ }^{1}$ Thomas B. Moorman, ${ }^{2}$ Thomas C. Kaspar, ${ }^{2}$ Andrew W. Lenssen, ${ }^{3}$ and Alison E. Robertson ${ }^{1, \dagger}$ \\ ${ }^{1}$ Department of Plant Pathology and Microbiology, Iowa State University, Ames, IA 50011 \\ ${ }^{2}$ National Laboratory for Agriculture and the Environment, USDA ARS, Ames, IA 50011 \\ ${ }^{3}$ Department of Agronomy, Iowa State University, Ames, IA 50011
}

\begin{abstract}
The effects of winter cover crops on root disease and growth of corn and soybeans are poorly understood. A 3-year field experiment investigated the effect of winter cereal rye (Secale cereale L.) and winter camelina (Camelina sativa [L.] Crantz), used either in all three years or in rotation with each other, on corn (Zea mays L.) and soybean (Glycine max. [L.] Merr.) growth, root disease, and yield. Corn following a cover crop of camelina had reduced root disease, a lower Pythium population in seedling roots, and greater growth and yields compared with corn following a

seedlings after a rye cover crop compared with those following a camelina cover crop, whereas clade $\mathrm{F}$ populations were greater on soybean seedlings following a camelina cover crop compared with seedlings following a rye cover crop. A winter camelina cover crop grown before corn had less-negative effects on corn seedling growth, root disease, and final yield than a winter rye cover crop before corn. Neither cover crop had negative effects on soybean, and the cover crop in the preceding spring had no measurable effects on either corn or soybean.
\end{abstract} rye cover crop. Camelina and rye cover crops before soybean had either a positive or no effect on soybean growth and development, root disease, and yield. Moreover, Pythium clade B populations were greater in corn
Keywords: cover crop, Pythium, seedling disease, disease management, field crops
Cover cropping of agricultural land is gaining popularity and interest because of benefits to long-term soil health and environmental sustainability. In 2017 Iowa farmers planted cover crops on 393,797 ha compared with 152,621 ha in 2012 (NASS 2017). Cover crops increase the diversity of the soil microbial community, help build soil organic matter, protect soil from erosion, suppress weeds, reduce nitrate leaching, recycle nitrogen and other nutrients for the next subsequent crops, and improve soil structure and water infiltration (Basche et al. 2016; Kaspar et al. 2007; Larkin et al. 2010; Moore et al. 2014; Sarrantonio and Gallandt 2003; Sturz et al. 1998; Villamil et al. 2006).

Additionally, cover crops have become an important component of state and regional scale initiatives to meet critical environmental challenges associated with large-scale agriculture. In the upper Midwest, incorporating winter cereal rye (Secale cereale L.) into the corn and soybean farming system is highly encouraged and has been promoted as one viable option for reaching water quality goals set in the Midwest (e.g., Iowa Nutrient Reduction Strategy [Iowa Department of Agriculture and Land Stewardship 2013]). Winter cereal rye is the most widely used cover crop in the upper Midwest because it is relatively easily to establish in the fall, has superior winter hardiness and documented environmental benefits, and has been used successfully in corn-soybean rotations (Kaspar and Bakker 2015; Snapp et al. 2005). Nevertheless, reduced corn yields have been reported following winter rye cover crops (Acharya et al. 2017; Kaspar and Bakker 2015; Miguez and Bollero 2005). This is puzzling because a winter cereal rye cover crop improves soil health (Ding et al. 2006; Moore et al. 2014), which should in theory increase corn yield.

${ }^{\dagger}$ Corresponding author: A. E. Robertson; alisonr@iastate.edu

Funding: The authors thank Iowa Nutrient Reduction Research Center and USDA Hatch Project \#IOWO3908 for partial funding for the project.

*The $\boldsymbol{e}$-Xtra logo stands for "electronic extra" and indicates that one supplementary table is published online.

The author(s) declare no conflict of interest.

Accepted for publication 25 October 2019.

C 2020 The American Phytopathological Society
A number of mechanisms have been proposed for corn yield decrease following a cereal rye cover crop, including water stress (Munawar et al. 1990), limited nitrogen availability (Karlen and Doran 1991; Tollenaar et al. 1993; Wagger and Mengel 1993), impaired planter performance (Duiker and Curran 2005), and allelopathy (Kessavalou and Walters 1997; Tollenaar et al. 1993). The effect, however, has been difficult to study because it does not occur every year, does not seem to occur in some fields, or does not occur for some farmers. Another possible cause of the corn yield decrease that may fit this pattern of variable occurrence is increased seedling disease. A cereal rye cover crop can provide a "green bridge" or living host for pathogens over winter that then can infect corn seedlings in spring (Bakker et al. 2016; Smiley et al. 1992). These pathogens can cause seed rot, lesions on roots and mesocotyls, slow growth, and sometimes seedling death (Acharya et al. 2017; Bakker et al. 2016; Schenck et al. 2017). Obviously, reductions in plant stand can have a direct effect on corn yield (Munkvold 1999; Nafziger et al. 1991). More often, however, seedling disease delays emergence and reduces plant vigor, which also can result in lower yields. Optimum corn yield often is dependent on uniform emergence, growth, and development (Nafziger et al. 1991). When plants are uneven in size, as often occurs with seedling disease, the smaller plants produce smaller ears or no ears, and thus, yields are reduced.

Our previous studies reported greater densities of Pythium spp. in the roots of corn seedlings following a winter cereal rye cover crop compared with the roots of corn seedlings grown following a winter fallow (Acharya et al. 2017). In a controlled environment study, Schenck et al. (2017) also reported greater clade B Pythium populations than clade F Pythium populations in radicle and mesocotyl tissues of corn seedlings following winter cereal rye, compared with those following a winter fallow, or nongrass cover crops of hairy vetch (Vicia villosa Roth) or canola (Brassica napus L.).

In contrast to corn, soybean yield is not usually reduced following a winter rye cover crop (Ruffo et al. 2004; Thelen and Leep 2002). This is somewhat surprising because soybeans are susceptible to some of the same Pythium and Fusarium spp. that a rye cover crop is known to host (Bakker et al. 2016, 2017; Matthiesen et al. 2016). Although seedling disease may reduce soybean stand like it does for corn, yield loss due to a reduction in soybean population is not as common (Bradley 2008). This is because soybean is planted at much higher seeding rates than corn and because soybean plants 
respond to random missing plants by producing new branches, pods, and seeds and often maintain adequate yields despite reductions in plant stand (Carpenter and Board 1997a, 1997b; Cox and Cherney 2011).

Assuming that corn seedling disease is one of the primary causes of poor corn growth and reduced population following a cereal rye cover crop, then the classical approach to many plant disease issues is to rotate or change the plant species that precedes the crop or plant affected by disease to a species that is not a host to those pathogens. In this case, that would mean using a different cover crop than rye preceding corn, which like corn is a grass species. Although many plant species are used as cover crops, the species selected often depends on several factors including local climate conditions, the length and season of the interval between cash crops, potential to overwinter, and the cost and availability of seed. In the upper Midwest corn-soybean rotations, the cover crop growing season from late fall to early spring is short and cold. As a result, winter cereal grain cover crops such as winter cereal rye, winter wheat (Triticum aestivum L.), and winter triticale (Triticale hexaploide Lart.) $(\times$ Triticosecale Wittm. ex A. Camus [Secale $\times$ Triticum] $)$ are often planted because they establish well in the fall, produce substantial biomass in late fall and early spring, usually overwinter, and are widely available (Singer et al. 2007; Snapp et al. 2005). Other popular cover crop species, such as hairy vetch (V. villosa) or oilseed radish (Raphanus sativus L.) either do not overwinter in the upper Midwest or do not produce much biomass by the time of corn planting in the spring when planted after soybean harvest. In recent years, winter camelina (Camelina sativa [L.] Crantz), a brassica species, has been reported to consistently overwinter in Minnesota and North Dakota (Berti et al. 2017; Gesch and Cermak 2011), and consequently it has drawn interest as a possible cover crop from upper Midwest researchers.

The goal of our research program is to develop best management practices to increase the adoption of cover crops by Iowa farmers in a corn-soybean production system. Although winter rye has been successfully managed as a cover crop by many farmers, adoption by additional farmers is limited by concerns of possible corn seedling disease and yield decreases following a winter rye cover crop. At this time, rotation of grass and broadleaf cover crop species have not been consistently used in the corn-soybean rotation in Iowa because of the difficulty of finding a broadleaf species that successfully overwinters and produces substantial biomass. Additionally, more work is also needed to determine the relationship of different cover crop species, such as camelina, to soil-borne diseases. We hypothesize that winter camelina grown as a broadleaf cover crop before corn could prevent the increased seedling disease and the reduced growth and yield sometimes seen following a winter rye cover crop. Additionally, we hypothesize that a cover crop rotation of winter camelina before corn and winter rye before soybean may be a good compromise between cover crop biomass production and limiting negative effects on corn and soybean yield than growing either winter camelina or winter rye cover crops every year without rotation. Thus, we established a field trial to evaluate the effect of winter rye and winter camelina cover crops, grown every winter or in rotation with each other in a corn-soybean rotation, on cover crop biomass and on corn and soybean seedling disease, growth, and yield.

\section{Materials and Methods}

Study location and experiment setup. Research plots were established at an Iowa State University Agricultural Engineering/ Agronomy research farm in Boone County, IA $\left(42^{\circ} 1^{\prime} 15^{\prime \prime} \mathrm{N}\right.$, $\left.93^{\circ} 46^{\prime} 26^{\prime \prime} \mathrm{W}\right)$, in $2015,2016,2017$, and 2018 . The field used in this experiment was in a corn-soybean rotation, with both cash crops of the rotation present each year, and used a no-till management system. The soils series at the field site were Nicollet loam, Clarion loam, and Webster clay loam. Each plot was an experimental unit containing five rows with a 76-cm interrow spacing and $53.3 \mathrm{~m}$ long. The experimental design was a split plot within a randomized complete block design with five blocks or replications. Main plot treatments were the cash crop rotation sequence (corn-soybean or soybean-corn). In each main plot, the cash crop rotated each year such that one main plot treatment started with corn in 2015 and the other with soybean. Main plots had one or more border plots on each side to minimize the border effects. At the beginning of the experiment, subplots within the main plots were randomly assigned with the five cover crop rotation treatments (camelina-camelina, rye-rye, camelina-rye, rye-camelina, no cover crop-no cover crop). Because cover crop treatments were first established in the fall of 2015, the 2016 subplots before either corn or soybean included two rye subplots, two camelina subplots, and one no cover crop plot to accommodate the cover crop rotation in future years (Table 1). In 2017, individual treatment subplots within each main plot consisted of one of the five cover crop rotation treatments shown above. However, because corn and soybean were rotated between main plots, main plots planted to corn in 2017 had been planted to soybean in 2016, and therefore the cover crops growing in spring 2017 preceded a different cash crop than in 2016. For example, for the rye-camelina cover crop rotation treatment planted in the corn main plots in 2017, the sequence of cover crops and cash crops would have been rye-soybean-camelina-corn planted in Fall 2015-Spring 2016-Fall 2016-Spring 2017, respectively (Table 1). Lastly, 2018 was also unique in that cover crops had been present in the plots in the spring of all three years on the experiment (i.e., 2016, 2017, and 2018). Again, for the rye-camelina cover crop rotation treatment planted in the corn main plots in 2018, the sequence of cover crops and cash crops would have been camelina-corn-rye-soybean-camelina-corn planted in Fall 2015Spring 2016-Fall 2016-Spring 2017- Fall 2017-Spring 2018, respectively (Table 1). Subplots assigned to the no cover crop treatment had no cover crop preceding the cash crop in any year. Table 1 shows the

Table 1. Cover crops and crop rotation sequences with treatment descriptions over the 3-year field study in Iowa

\begin{tabular}{|c|c|c|c|c|c|c|c|c|}
\hline $\begin{array}{l}\text { Cover crop } \\
\text { in Fall 2015 }\end{array}$ & $\begin{array}{l}\text { Cash } \\
\text { crop in } \\
2016\end{array}$ & $\begin{array}{c}\text { Treatment } \\
\text { description before } \\
\text { corn and soybean } \\
\text { in } 2016^{\mathrm{z}}\end{array}$ & $\begin{array}{l}\text { Cover crop in } \\
\text { Fall 2016 }\end{array}$ & $\begin{array}{l}\text { Cash } \\
\text { crop in } \\
2017\end{array}$ & $\begin{array}{c}\text { Treatment } \\
\text { description before } \\
\text { corn and soybean } \\
\text { in } 2017^{\mathrm{z}}\end{array}$ & $\begin{array}{l}\text { Cover crop in } \\
\text { Fall 2017y }\end{array}$ & $\begin{array}{l}\text { Cash } \\
\text { crop in } \\
2018\end{array}$ & $\begin{array}{l}\text { Treatment description } \\
\text { before corn and } \\
\text { soybean in } \mathbf{2 0 1 8}^{\mathrm{z}}\end{array}$ \\
\hline $\begin{array}{l}\text { No cover } \\
\text { crop }\end{array}$ & Corn & $\mathrm{NC}-\mathrm{C}$ & No cover crop & Soybean & NC-C/NC-S & No cover crop & Corn & NC-C/NC-S/NC-C \\
\hline Rye & Corn & Rye-C & Rye & Soybean & Rye-C/Rye-S & Rye & Corn & Rye-C/Rye-S/Rye-C \\
\hline Camelina & Corn & Cam-C & Camelina & Soybean & Cam-C/Cam-S & Camelina & Corn & Cam-C/Cam-S/Cam-C \\
\hline Camelina & Corn & Cam-C & Rye & Soybean & Cam-C/Rye-S & Camelina & Corn & Cam-C/Rye-S/Cam-C \\
\hline Rye & Corn & Rye-C & Camelina & Soybean & Rye-C/Cam-S & Rye & Corn & Rye-C/Cam-S/Rye-C \\
\hline $\begin{array}{l}\text { No cover } \\
\text { crop }\end{array}$ & Soybean & $\mathrm{NC}-\mathrm{S}$ & No cover crop & Corn & NC-S/NC-C & No cover crop & Soybean & NC-S/NC-C/NC-S \\
\hline Rye & Soybean & Rye-S & Rye & Corn & Rye-S/Rye-C & Rye & Soybean & Rye-S/Rye-C/Rye-S \\
\hline Camelina & Soybean & Cam-S & Camelina & Corn & Cam-S/Cam-C & Camelina & Soybean & Cam-S/Cam-C/Cam-S \\
\hline Camelina & Soybean & Cam-S & Rye & Corn & Cam-S/Rye-C & Camelina & Soybean & Cam-S/Rye-C/Cam-S \\
\hline Rye & Soybean & Rye-S & Camelina & Corn & Rye-S/Cam-C & Rye & Soybean & Rye-S/Cam-C/Rye-S \\
\hline
\end{tabular}

${ }^{y}$ Cover crops were established in a corn-soybean rotation field that included both cash crops of the rotation present each year. Cover crops in this study were terminated 3 days before planting corn or soybean.

${ }^{\mathrm{z}}$ Abbreviations: $\mathrm{NC}=$ no cover crop; $\mathrm{Cam}=$ camelina; $\mathrm{C}=$ corn; and $\mathrm{S}=$ soybean. 
sequence of cover crops treatments and cash crops for each year. Data from each year and cash crop will be presented separately because of the differing number of years the cover crop rotation was in place.

Cover crop and cash crop planting. Cover crops were planted each fall using a grain drill with $15.25-\mathrm{cm}$ row spacing after soybean harvest (16 September 2015, 15 September 2016, and 30 September 2017) and corn harvest (2 October 2015 and 10 October 2016 and 2017), at a rate of $67.25 \mathrm{~kg} / \mathrm{ha}$ for rye (cv. Elbon) and $2.75 \mathrm{~kg} / \mathrm{ha}$ for camelina (cv. Joelle). The camelina seed used in 2015 was mistakenly a mixture of the winter camelina cultivar Joelle and an unknown spring camelina cultivar, which reduced winter survival and population in spring 2016 (personal observation). After the establishment, fall cover crop stand count data were collected in all plots during the second week of November in all three years. The following spring, cover crops were terminated 3 days before the cash crop was planted by spraying with glyphosate at $1.12 \mathrm{~kg}$ of active ingredient per hectare. The no cover crop control plots were also sprayed with glyphosate for consistency of exposure to glyphosate and to manage weeds, even though very few winter annual weeds were present.

Cover crop shoot biomass samples were collected one day prior to or one day after spraying from two arbitrary locations in each plot designated using a rectangular frame $(0.76 \mathrm{~m}$ wide by $0.50 \mathrm{~m}$ long). Plants were clipped close to the soil surface, placed in a paper bag, dried at $60^{\circ} \mathrm{C}$ in a forced-air oven, and weighed to determine cover crop shoot dry biomass. Combined subsamples were finely ground and analyzed for carbon and nitrogen concentration using the dry combustion-gas chromatograph method (Schepers et al. 1989) with an EA1112 Flash NC Elemental analyzer (Thermo Electron Corp., Waltham, MA). Carbon and nitrogen contents were calculated by multiplying cover crop shoot biomass on an area basis by tissue nitrogen concentration.

A commercial corn hybrid (PO448AMI; DuPont-Pioneer Hybrid International, Johnston, IA) and a soybean variety (Viking 0878R2n; Albert Lea Seed Co., Albert Lea, MN) were planted 3 days after rye termination. Corn was planted on 3 May 2016, 25 April 2017, and 30 April 2018 at a seeding rate of 86,487 seeds/ha in $0.75-\mathrm{m}$ rows using a five-row no-till planter. Soybean was planted at 444,789 seeds/ha on 5 May 2016, 8 May 2017, and 8 May 2018 using the same planter that was used to plant corn. Average monthly air temperatures and precipitation were obtained from the weather station located approximately $0.5 \mathrm{~km}$ from the experimental site (Iowa Environmental Mesonet, https://mesonet.agron.iastate.edu/). Soil temperature at the $5-\mathrm{cm}$ depth was monitored in one subplot for each cash crop and cover crop rotation treatment combination using thermocouples (copper-constantan) attached to a data logger (21X Micrologger; Campbell Scientific, Logan, UT).

Corn plots were fertilized with urea ammonium nitrate injected at planting $5 \mathrm{~cm}$ from the corn row at $33.6 \mathrm{~kg}$ of N/ha and injected at the V4 to V5 plant stage $19 \mathrm{~cm}$ from the plant row at $201.8 \mathrm{~kg}$ of N/ha. In the fall of 2015, 2016, and 2017 a dry mixture of monoammonium phosphate and potassium chloride was surface broadcast at a rate of $19 \mathrm{~kg}$ of N/ha, $40 \mathrm{~kg}$ of P/ha, and $199 \mathrm{~kg}$ of K/ha, as indicated by soil tests and nutrient removal rates.

Sample collection and processing. In 2016 and 2018, corn seedlings were sampled at the V4 to V5 developmental stage (Abendroth et al. 2011; Pedersen 2007), whereas in 2017 corn seedlings were sampled at the V2 to V3 developmental stage. Soybean seedlings were sampled at the developmental stage V2 in both 2016 and 2017, whereas in 2018 soybean seedlings were sampled at the V4 to V5 developmental stage. Although we planned to sample corn and soybean at the same developmental stage, we were prevented from going to the field to sample by wet field conditions. Six seedlings, three from row 2 and three from row 4 of each five-row plot, were dug out using a spade. The soil was carefully removed and roots cleaned with water. Bagged samples were transported to the lab on ice, and then seedling shoot height, shoot dry weight, and disease assessments were measured in the lab. Corn shoot height was measured from the base of the shoot to the tip of the longest extended leaf. Soybean shoot height was measured from soil level, as indicated by color change on the hypocotyl, to the tip of the apical meristem. Root disease was assessed as described in Acharya et al. (2017, 2018). Briefly, root rot incidence was estimated based on the presence or absence of lesions observed on the root tissue (i.e., radicle, seminal, nodal, and mesocotyl). Disease severity was assessed as the percentage of root tissue rotted and then converted to a 0 to 5 scale, where 1 , $2,3,4$, and $5=1$ to $10 \%, 11$ to $25 \%, 26$ to $50 \%, 51$ to $75 \%$, and 76 to $100 \%$ of roots covered with lesions, respectively (Acharya et al. 2017). Healthy plants with no visible lesions were assigned a value of 0 . Disease incidence and disease severity were combined into a single disease index, using the formula disease index $=$ disease incidence $\times$ disease severity/5 (Kandel et al. 2015; Li et al. 2013). A similar scale was used to assess soybean root rot incidence and severity for taproot and the hypocotyl. After disease assessments, shoot dry weight of the seedlings was determined by weighing after drying in a forced air oven at $60^{\circ} \mathrm{C}$.

In 2017 and 2018, samples of corn radicles and mesocotyls, and soybean taproots and hypocotyls, were collected from seedlings collected for the visual disease assessment to determine the density of Pythium spp. belonging to clade B and clade F present in those tissues. Samples were not collected in 2016 because we were not ready at that time to implement the procedure at that scale. In preparation for DNA extraction, sampled corn and soybean roots were washed with tap water and rinsed with sterile distilled water. Root tissue samples of approximately $2 \mathrm{~cm}$ length were taken from either the root tip or zone of elongation from radicles of corn and taproot of soybean regardless of disease symptoms observed. However, most of the mesocotyl and hypocotyl tissues were included for DNA processing. Prior to drying, two subsamples of approximately $100 \mathrm{mg}$ fresh weight from the above collected tissue types were collected and prepared for DNA extraction using a Qiagen DNA extraction kit (cat. no. 69106).

The density of Pythium spp. belonging to clade B and clade F present in corn and soybean root tissues was measured using quantitative polymerase chain reaction (qPCR) (BIO-RAD IQ5, IDT, Coralville, IA) following the method described by Acharya et al. (2017). Clade B and clade F Pythium spp. were targeted, because prior work indicated members of these clades constituted the majority of Pythium spp. associated with corn and soybean seedling disease in Iowa (Acharya et al. 2017; Bakker et al. 2017; Matthiesen et al. 2016). Due to an error in the sampling process of the 2018 corn mesocotyl tissue, only data for 2017 corn mesocotyl tissue was reported in the current study.

To remove possible errors associated with DNA extraction efficiencies among samples, pathogen DNA present in corn and soybean tissues was expressed relative to corn and soybean DNA content; that is, copies of Pythium ITS gene per million copies of $\alpha$-tubulin (tua4) gene for corn using the assay of Mideros et al. (2009) and copies of Pythium ITS gene per million copies of cyclophilin (CYP2) gene for soybean using the assay of Jian et al. (2008) with a slight modification for the soybean assay. Briefly, each reaction was performed in $20 \mu \mathrm{l}$, which consisted of $5 \mu \mathrm{l}$ of DNA template equal to $50 \mathrm{ng}$, $10 \mu$ l of SYBR Green Master Mix (Qiagen, cat. no. 204143 or 204163), and $0.6 \mu 1$ each of CYP2F and CYP2R primers (Jian et al. 2008) at $300 \mathrm{nM}$ final concentration. The tua4 gene sequence was obtained from a GenBank reference sequence (x73980.1), and the $C Y P 2$ gene sequence was obtained from an NCBI reference sequence (NM_001357079.1). The standard curves of synthesized tua4 and CYP2 genes (IDT, https://www.idtdna.com/pages) for corn and soybean spanning six orders of magnitude in copy number were prepared. Quantification was done only within the range of standard curve amplification. Amplifications with cycle threshold above 37 were assigned as nondetects. The following thermocycler program was used: $10 \mathrm{~min}$ at $95^{\circ} \mathrm{C}$, followed by 40 cycles of denaturing for $10 \mathrm{~s}$ at $95^{\circ} \mathrm{C}$ and annealing and extension for $30 \mathrm{~s}$ at $60^{\circ} \mathrm{C}$. Across qPCR runs, the standard curves always produced an $R^{2}>0.99$, and calculated PCR efficiencies were in the range of 90 to $105 \%$. Measured pathogen densities in corn and soybean tissue were expressed as pathogen ITS gene copies per million copies of the corn tua4 gene and soybean $C Y P 2$ gene and then $\log _{10}$ transformed. 
Agronomic assessments. At the end of the season, the number of corn plants, ears, and barren plants were recorded from the center row 18.3-m-long section of each plot. Corn yield data were collected from the middle three rows of the entire five-row plots on 4 October 2016, 12 October 2017, and 27 September 2018. Similarly, the numbers of soybean plants were recorded from a 5.2-m section of each plot, and the yield was obtained from the entire five-row plots on 29 September 2016, 20 September 2017, and 17 September 2018. A modified combine (Colvin 1990) was used to harvest and measure corn and soybean grain yield and grain moisture. Yields were adjusted to 0.15 and $0.13 \mathrm{~g} / \mathrm{g}$ grain moisture contents for corn and soybean, respectively.

Statistical analyses. Analysis of variance (ANOVA) was performed for all variables using PROC GLIMMIX in SAS version 9.3 (SAS Institute, Cary, NC). Fixed effect factors were cover crop rotation treatments, and replications were a random effect factor. Data were analyzed separately for corn and soybean measurements for each year to examine cover crop rotation treatments within each year. This analysis was planned during experimental design because the history or rotation sequence of cover crops changed with each succeeding year and because of expected variation of cover crop growth and weather among years. Cover crop rotation treatment means were compared using Fisher's protected LSD at $P=0.05$ when the ANOVA indicated significant treatment differences at the 0.05 level of significance.

\section{Results}

Average monthly air temperature and precipitation. Average monthly air temperature and precipitation profiles differed each year. The fall (October through November) of 2015 and 2016 when cover crops were planted and established was warmer and drier than the fall 2017 (Table 2). Similarly, spring (March through April) air temperatures, which are important for early growth of cover crops, were 6 to $7.5^{\circ} \mathrm{C}$ warmer in 2016 and 2.5 to $7^{\circ} \mathrm{C}$ warmer in 2017 compared with the same period in 2018 (Table 3). In fact, April 2018 was $6.6^{\circ} \mathrm{C}$ below the 30-year average temperature, whereas in 2016 and 2017 April average temperatures were above the 30 -year average. Conversely, air temperatures during May 2018 after the cash crops were planted were warmer compared with May 2017 and warmer than the 30-year average for May. Precipitation varied during each growing season (May through August; Table 3). In general, there was more precipitation in 2018 compared with 2017, except for May.

Table 2. Average monthly air temperature $\left({ }^{\circ} \mathrm{C}\right)$ and precipitation (millimeters) from September to December 2015, 2016, and 2017 obtained from a weather recording station located $2 \mathrm{~km}$ from the experimental site

\begin{tabular}{lcrrrrrr}
\hline & \multicolumn{3}{c}{ Temperature $\left({ }^{\circ} \mathbf{C}\right)$} & & \multicolumn{3}{c}{ Precipitation $(\mathbf{m m})$} \\
\cline { 2 - 3 } \cline { 7 - 8 } Month & $\mathbf{2 0 1 5}$ & $\mathbf{2 0 1 6}$ & $\mathbf{2 0 1 7}$ & & $\mathbf{2 0 1 5}$ & $\mathbf{2 0 1 6}$ & $\mathbf{2 0 1 7}$ \\
\hline September & 20.9 & 20.6 & 20.0 & & 128.3 & 200.2 & 74.1 \\
October & 12.4 & 14.5 & 11.9 & & 32.3 & 12.0 & 160.5 \\
November & 6.04 & 8.2 & 2.3 & & 69.6 & 44.2 & 6.1 \\
December & 0.46 & -4.1 & -3.7 & & 131.8 & 30.8 & 11.1 \\
\hline
\end{tabular}

Average soil temperature at the 5-cm depth in corn plots preceding camelina, fallow, and rye from planting cash crop to sampling cash crop ranged from 20.1 to $20.6^{\circ} \mathrm{C}$ in $2016,15.4$ to 15.9 in 2017 , and 20.3 to 20.8 in 2018 , respectively (results not shown). Similarly, in soybean plots, average soil temperature at the $5-\mathrm{cm}$ depth preceding camelina, fallow, and rye ranged from 21.1 to 22.2 in $2016,16.8$ to 17.1 in 2017 , and 21.2 to 21.7 in 2018 , respectively (results not shown).

Cover crop and its rotation effect on fall stand count. Cover crop stands were denser when planted after soybean harvest compared with planting after corn harvest in all three years (Table 4). Moreover, cover crop stand densities were much lower in the first year of the trial establishment compared with the second and the third year. In general, stand densities of rye were greater than those of camelina after both corn and soybean harvest during the study period.

Cover crop spring biomass. Cover crop shoot biomass was considerably lower in spring 2018 compared with spring 2016 and 2017 preceding both corn and soybean (Table 5). An effect of previous year cash crop on spring cover crop biomass accumulation was observed in 2017 only $(P<0.03)$. Spring cover crop biomass of rye was greater than that of camelina in all three years (Table 5). However, less spring biomass of camelina in 2016 was due to planting the mixture of winter and spring camelina cultivars this one year. Total nitrogen content in cover crop shoots was considerably greater in rye than camelina. Average rye shoot nitrogen in treatments with rye before corn or soybean in all three years or camelina in the previous year before soybean or corn averaged across years was 40 to $42 \mathrm{~kg} / \mathrm{ha}$ preceding corn and 44 to $45 \mathrm{~kg} / \mathrm{ha}$ preceding soybean (results not shown). On the other hand, camelina shoot nitrogen ranged from 18 to $19 \mathrm{~kg} / \mathrm{ha}$ preceding corn and from 17 to $18 \mathrm{~kg} / \mathrm{ha}$ preceding soybean (results not shown).

Cover crop effects on corn seedling growth and disease. The effects of cover crop rotation treatments were significant in at least one year for most measured parameters of corn seedlings such as corn shoot height, leaf stage, shoot dry weight, radicle root rot incidence, and radicle disease index (Table 6).

No effect of cover crop treatments on corn seedling height was detected in 2016 and $2018(P=0.06, P=0.12$; Table 6). In 2017, corn seedling height was shortest in the no cover crop treatment compared with three of the cover crop rotation treatments (Cam-S/Rye-C, CamS/Cam-C, Rye-S/Cam-C). Additionally, the Cam-S/Rye-C treatment had significantly taller corn plants than the Rye-S/Rye-C treatment, indicating a possible effect of the previous cover crop before soybean. In all three years, corn leaf stage of seedlings was lowest with rye before corn (Rye-S/Rye-C or Cam-S/Rye-C) compared with no cover crop or camelina before corn, regardless of the cover crop species in the previous spring before soybean. No difference in corn leaf stage was observed between seedlings after camelina and no cover crop. Additionally, shoot dry weight was greater for seedlings following camelina and no cover crop than those following a rye cover crop in all three years. In 2018, corn shoot dry weights following no cover crop also were greater than those of corn following a camelina cover crop (Cam-S/Cam-R, Rye-S/Cam-C). Except for shoot height in 2017 , the cover crop grown in the previous spring before soybean did not affect corn shoot growth in either 2017 or 2018.

Table 3. Average monthly air temperature $\left({ }^{\circ} \mathrm{C}\right.$ ) and precipitation (millimeters) from January to August 2016, 2017, and 2018 and the cumulative 30 -year average temperature and precipitation obtained from a weather recording station located $2 \mathrm{~km}$ from the experimental site

\begin{tabular}{|c|c|c|c|c|c|c|c|c|}
\hline \multirow[b]{2}{*}{ Month } & \multicolumn{4}{|c|}{ Temperature $\left({ }^{\circ} \mathbf{C}\right)$} & \multicolumn{4}{|c|}{ Precipitation $(\mathrm{mm})$} \\
\hline & 2016 & 2017 & 2018 & 30-year average & 2016 & 2017 & 2018 & 30-year average \\
\hline January & -6.5 & -3.9 & -8.6 & -5.9 & 15.3 & 47.0 & 43.3 & 21.3 \\
\hline February & -1.7 & 2.6 & -7.3 & -4.1 & 21.4 & 55.3 & 50.6 & 25.4 \\
\hline March & 7.0 & 3.8 & 1.3 & 3.4 & 38.6 & 83.3 & 85.2 & 61.2 \\
\hline April & 11.1 & 11.5 & 3.6 & 10.2 & 108.8 & 116.7 & 66.8 & 102.6 \\
\hline May & 16.3 & 16.3 & 20.7 & 16.7 & 109.0 & 189.4 & 82.1 & 128.1 \\
\hline June & 23.7 & 22.7 & 23.5 & 21.7 & 24.4 & 49.3 & 281.9 & 129.6 \\
\hline July & 23.5 & 24.4 & 23.5 & 23.3 & 148.6 & 37.4 & 106.9 & 120.6 \\
\hline August & 22.7 & 20.8 & 16.6 & 22.2 & 209.1 & 92.9 & 217.7 & 129.2 \\
\hline
\end{tabular}


In general, radicle root rot incidence assessed at corn growth stages V2 to V4 was usually lowest for corn seedlings following the no cover crop treatment (Table 6). In 2017, more corn seedlings following a rye cover crop (Rye-S/Rye-C or Cam-S/Rye-C) had radicle lesions than either seedings following a camelina cover crop (Cam-S/ Cam-R, Rye-S/Cam-C) or the no cover crop treatment. In 2018, radicle root rot incidence did not differ among seedlings following either camelina or rye cover crops, but all four of those treatments were significantly greater than the no cover crop treatment. No difference in radicle root rot incidence was detected in corn when it followed a rye cover crop regardless of if rye or camelina was used as a cover crop species in rotation before soybean in the previous year $(P=0.54$ in
2017, and $P=0.85$ in 2018, data analysis not shown). An effect of cover crop treatment on radicle root rot index was only detected in 2017, and it was greater preceding rye compared with other treatments; however, the effect was not as consistent as the radicle root rot incidence.

Cover crop rotation treatments had no detectable effect on seminal root rot incidence in 2016 and 2018 (Table 6). In 2017, the seminal root rot incidence was greater for corn seedlings only following the Cam-S/Rye-C treatment than the no cover crop treatment. However, Rye-S/Rye-C treatment was close to being significantly different from the no cover crop treatment. Seminal root rot incidence for corn planted after a cover crop of camelina (Cam-S/Cam-R, Rye-S/Cam-C)

Table 4. Fall cover crop stand count before corn and soybean in 2015, 2016, and 2017 in field experiments in Iowa

\begin{tabular}{|c|c|c|c|c|c|c|c|c|}
\hline Year & $\begin{array}{l}\text { Treatments from } \\
\text { corn plots }^{x}\end{array}$ & $\begin{array}{c}\text { Cover crop } \\
\text { previous } \\
\text { spring before } \\
\text { soybean }\end{array}$ & $\begin{array}{l}\text { Cover crop } \\
\text { fall/spring } \\
\text { before corn }\end{array}$ & $\begin{array}{l}\text { Cover crop } \\
\text { stand count } \\
\text { before corn } \\
\left(\text { plants } / \mathbf{m}^{2}\right)^{y}\end{array}$ & $\begin{array}{l}\text { Treatments from } \\
\text { soybean plots }^{\mathrm{x}}\end{array}$ & $\begin{array}{c}\text { Cover crop } \\
\text { previous } \\
\text { spring before } \\
\text { corn }\end{array}$ & $\begin{array}{c}\text { Cover crop } \\
\text { fall/spring } \\
\text { before } \\
\text { soybean }\end{array}$ & $\begin{array}{c}\text { Cover crop } \\
\text { stand count } \\
\text { before soybean } \\
(\text { plants/m²)y }\end{array}$ \\
\hline \multirow{5}{*}{$\begin{array}{l}\text { Fall } \\
2015\end{array}$} & Rye-C & None & Rye & 188.8 & Rye-S & None & Rye & 80.0 \\
\hline & Cam-C & None & Camelina & 199.6 & Cam-S & None & Camelina & 99.4 \\
\hline & Cam-C & None & Camelina & 119.0 & Cam-S & None & Camelina & 102.5 \\
\hline & Rye-C & None & Rye & 180.8 & Rye-S & None & Rye & 90.6 \\
\hline & $P$ value & & & 0.08 & $P$ value & & & 0.43 \\
\hline \multirow{5}{*}{$\begin{array}{l}\text { Fall } \\
2016\end{array}$} & Rye-S/Rye-C & Rye & Rye & $345.4 \mathrm{a}^{\mathrm{z}}$ & Rye-C/Rye-S & Rye & Rye & $155.0 \mathrm{a}$ \\
\hline & Cam-S/Cam-C & Camelina & Camelina & $323.0 \mathrm{ab}$ & Cam-C/Cam-S & Camelina & Camelina & $120.6 \mathrm{ab}$ \\
\hline & Rye-S/Cam-C & Rye & Camelina & 246.2 b & Rye-C/Cam-S & Rye & Camelina & $83.4 \mathrm{~b}$ \\
\hline & Cam-S/Rye-C & Camelina & Rye & $363.0 \mathrm{a}$ & Cam-C/Rye-S & Camelina & Rye & $168.0 \mathrm{a}$ \\
\hline & $P$ value & & & 0.05 & $P$ value & & & 0.02 \\
\hline \multirow{5}{*}{$\begin{array}{l}\text { Fall } \\
2017\end{array}$} & Rye-C/Rye-S/Rye-C & Rye & Rye & 295.0 & Rye-S/Rye-C/Rye-S & Rye & Rye & $189.4 \mathrm{a}$ \\
\hline & Cam-C/Cam-S/Cam-C & Camelina & Camelina & 288.6 & Cam-S/Cam-C/Cam-S & Camelina & Camelina & $53.8 \mathrm{~b}$ \\
\hline & Cam-C/Rye-S/Cam-C & Rye & Camelina & 292.2 & Cam-S/Rye-C/Cam-S & Rye & Camelina & $55.3 \mathrm{~b}$ \\
\hline & Rye-C/Cam-S/Rye-C & Camelina & Rye & 294.2 & Rye-S/Cam-C/Rye-S & Camelina & Rye & $144.2 \mathrm{a}$ \\
\hline & $P$ value & & & 0.99 & $P$ value & & & $<0.01$ \\
\hline
\end{tabular}

x Abbreviations: Cam = camelina; $\mathrm{C}=$ corn; and $\mathrm{S}=$ soybean.

y After the establishment of cover crops, fall cover crop stand count data were collected in all plots in the second week of November. Cover crops were counted from 1-ft sections of a row.

$\mathrm{z}$ Values followed by the same letter within a column are not significantly different at $P$ value 0.05 .

Table 5. Cover crop biomass before cash crop planting in spring 2016, 2017, and 2018 in field experiments in Iowa

\begin{tabular}{|c|c|c|c|c|c|c|c|c|}
\hline Year & $\begin{array}{l}\text { Treatments from } \\
\text { corn plots }^{x}\end{array}$ & $\begin{array}{l}\text { Cover crop } \\
\text { previous } \\
\text { spring before } \\
\text { soybean }\end{array}$ & $\begin{array}{c}\text { Cover crop } \\
\text { fall/spring } \\
\text { before corn }\end{array}$ & $\begin{array}{c}\text { Cover crop } \\
\text { biomass before } \\
\text { corn }(\mathrm{Mg} / \mathrm{ha})^{\mathrm{y}}\end{array}$ & $\begin{array}{l}\text { Treatments from } \\
\text { soybean plots }\end{array}$ & $\begin{array}{l}\text { Cover crop } \\
\text { previous } \\
\text { spring before } \\
\text { corn }\end{array}$ & $\begin{array}{c}\text { Cover crop } \\
\text { fall/spring } \\
\text { before } \\
\text { soybean }\end{array}$ & $\begin{array}{c}\text { Cover crop } \\
\text { biomass before } \\
\text { soybean } \\
(\mathrm{Mg} / \mathrm{ha})^{\mathrm{y}}\end{array}$ \\
\hline \multirow{5}{*}{$\begin{array}{l}\text { Spring } \\
2016\end{array}$} & Rye-C & None & Rye & $4.0 \mathrm{a}^{\mathrm{z}}$ & Rye-S & None & Rye & $4.8 \mathrm{a}$ \\
\hline & Cam-C & None & Camelina & $0.3 \mathrm{~b}$ & Cam-S & None & Camelina & $0.9 \mathrm{~b}$ \\
\hline & Cam-C & None & Camelina & $0.5 \mathrm{~b}$ & Cam-S & None & Camelina & $1.0 \mathrm{~b}$ \\
\hline & Rye-C & None & Rye & $4.6 \mathrm{a}$ & Rye-S & None & Rye & $4.2 \mathrm{a}$ \\
\hline & $P$ value & & & $<0.01$ & $P$ value & & & $<0.01$ \\
\hline \multirow{5}{*}{$\begin{array}{l}\text { Spring } \\
2017\end{array}$} & Rye-S/Rye-C & Rye & Rye & $3.1 \mathrm{a}$ & Rye-C/Rye-S & Rye & Rye & $1.9 \mathrm{~b}$ \\
\hline & Cam-S/Cam-C & Camelina & Camelina & $1.4 \mathrm{~b}$ & Cam-C/Cam-S & Camelina & Camelina & $0.6 \mathrm{c}$ \\
\hline & Rye-S/Cam-C & Rye & Camelina & $1.3 \mathrm{~b}$ & Rye-C/Cam-S & Rye & Camelina & $0.5 \mathrm{c}$ \\
\hline & Cam-S/Rye-C & Camelina & Rye & $3.2 \mathrm{a}$ & Cam-C/Rye-S & Camelina & Rye & $3.0 \mathrm{a}$ \\
\hline & $P$ value & & & $<0.01$ & $P$ value & & & $<0.01$ \\
\hline \multirow{5}{*}{$\begin{array}{l}\text { Spring } \\
2018\end{array}$} & Rye-C/Rye-S/Rye-C & Rye & Rye & $1.2 \mathrm{a}$ & Rye-S/Rye-C/Rye-S & Rye & Rye & $1.6 \mathrm{a}$ \\
\hline & Cam-C/Cam-S/Cam-C & Camelina & Camelina & $0.5 \mathrm{~b}$ & Cam-S/Cam-C/Cam-S & Camelina & Camelina & $0.3 \mathrm{~b}$ \\
\hline & Cam-C/Rye-S/Cam-C & Rye & Camelina & $0.6 \mathrm{~b}$ & Cam-S/Rye-C/Cam-S & Rye & Camelina & $0.4 \mathrm{~b}$ \\
\hline & Rye-C/Cam-S/Rye-C & Camelina & Rye & $1.3 \mathrm{a}$ & Rye-S/Cam-C/Rye-S & Camelina & Rye & $1.3 \mathrm{a}$ \\
\hline & $P$ value & & & $<0.01$ & $P$ value & & & $<0.01$ \\
\hline
\end{tabular}

\footnotetext{
x Abbreviations: Cam = camelina; $\mathrm{C}=$ corn; and $\mathrm{S}=$ soybean.

y Cover crops' spring biomass was collected at the time of termination using a rectangular frame ( $0.76 \mathrm{~m}$ wide by $0.50 \mathrm{~m})$. Collected shoot biomass was dried at $60^{\circ} \mathrm{C}$ and weighed.

${ }^{\mathrm{z}}$ Values followed by the same letter within a column are not significantly different at $P$ value 0.05 .
} 
was significantly reduced compared with that of corn planted after rye and was not different from that of corn planted following no cover crop. No difference in seminal root rot incidence was detected in corn when it followed a rye cover crop regardless of whether rye (Rye-S/ Rye-C) or camelina (Cam-S/Rye-C) was used as a cover crop species before soybean in the previous year $(P=0.69$ in 2017). Similarly, planting camelina before corn in 2017 (i.e., in treatments Cam-S/ Cam-C, Rye-S/Cam-C) reduced the radicle root rot index regardless of the cover crop planted in fall of 2015 before soybean. No significant effect of cover crop treatment was detected on the seminal root rot index in any year.

Although some lesions were observed on both the nodal roots and mesocotyls of corn seedlings sampled from all treatments with and without cover crops before corn, root rot incidence was generally minimal (less than 5\%), and no significant differences were detected. Therefore, only data for the radicles and the seminal roots are presented.

Cover crop effects on soybean seedling growth and disease. No effect of cover crop treatments was detected on soybean seedling shoot height in 2016 and 2018, on leaf stage in 2016 and 2017, and on shoot dry weight in 2017 (Table 7). In the first year of our trial, 2016 , one of the two treatments with rye preceding soybean had smaller shoot dry weights than the other treatments, including the other rye treatment. In 2017, a cereal rye cover crop preceding the soybean crop (Rye-C/Rye-S, Cam-C/Rye-S) increased soybean shoot height relative to the no cover crop control or when camelina preceded soybean (Cam-C/Cam-S, Rye-C/Cam-S). In contrast, in 2018 soybean plants following a cereal rye cover crop had lower leaf stages and smaller shoot dry weights than the other treatments. In all cases, the cover crop in the preceding year before corn did not affect the soybean response.

No root lesions or very low root rot incidence (less than 5\%) was observed among soybean seedlings sampled from all cover crop treatments as well as the no cover crop control, and consequently soybean root rot data are not presented.
Quantifying oomycete populations in corn and soybean root tissue. Oomycete populations in corn. Cover crop treatment effects were detected for Pythium clade B densities in 2017 and for clade F population densities in both 2017 and 2018 on radicle root tissue (Table 8). In general, greater populations of clade B were detected in corn seedlings planted after a cover crop of winter rye compared with either seedlings planted after a cover crop of camelina or seedlings planted after no cover crop treatment. Surprisingly, the cover crop treatment that included rye in the previous spring before soybean and camelina before corn (Rye-S/Cam-C) also showed greater clade B densities than the no cover crop control. Densities of Pythium clade F populations in corn following cover crop treatments were much lower than those of clade B, and interestingly, in both 2017 and 2018 corn planted after a rye cover crop had densities of clade F Pythium species that were not different from the no cover crop control, whereas in both years at least one of the treatments with corn following camelina had higher densities than the control.

For corn mesocotyl tissue in 2017, cover crop treatment effects only were observed for Pythium clade F members $(P<0.01)$. As observed in corn radicle tissues, clade $\mathrm{F}$ densities were greater in corn seedlings planted after camelina than those planted after rye. No significant effect of cover crop treatments was observed on clade B populations of Pythium. Although the differences were not significant, the relative ranking of means was similar to that observed for the corn radicles with corn seedlings following rye having the greatest values and those following no cover crop or camelina having lower values.

Oomycete populations in soybean. No effect of cover crop treatments was detected for Pythium clade B densities in soybean taproots or hypocotyls in both 2017 and 2018 (Table 9). Greater populations of clade F only were detected in hypocotyl tissues of soybeans in 2017 when camelina was planted as a cover crop before soybean in 2017 and in the previous year before corn (Cam-C/Cam-S) than in soybeans from the other treatments.

Cover crop effects on corn and soybean in the field. Corn yield and agronomic assessments. Final corn stands count and the number

Table 6. Average effects of cover crop treatments on corn seedling growth and root disease assessed at growth stage V2 to V4 in field experiments in Iowa from 2016, 2017, and 2018

\begin{tabular}{|c|c|c|c|c|c|c|c|c|c|c|c|}
\hline Year & Treatments & $\begin{array}{c}\text { Cover } \\
\text { crop Fall } \\
2015\end{array}$ & $\begin{array}{c}\text { Cover } \\
\text { crop Fall } \\
2016\end{array}$ & $\begin{array}{c}\text { Cover } \\
\text { crop Fall } \\
2017\end{array}$ & $\begin{array}{c}\text { Shoot } \\
\text { height } \\
(\mathbf{c m})^{t}\end{array}$ & $\begin{array}{l}\text { Leaf } \\
\text { stage }\end{array}$ & $\begin{array}{c}\text { Shoot } \\
\text { dry } \\
\text { weight } \\
(g)^{\mathbf{u}}\end{array}$ & $\begin{array}{c}\text { Radicle RR } \\
\text { incidence } \\
(\%)^{\mathbf{v}}\end{array}$ & $\begin{array}{c}\text { Radicle } \\
\text { RR index } \\
(\%)^{\mathrm{w}}\end{array}$ & $\begin{array}{c}\text { Seminal RR } \\
\text { incidence } \\
(\%)^{x}\end{array}$ & $\begin{array}{c}\text { Seminal } \\
\text { RR index } \\
(\%)^{y}\end{array}$ \\
\hline \multirow[t]{6}{*}{2016} & $\mathrm{NC}-\mathrm{C}$ & $\mathrm{NC}$ & NA & NA & 43.0 & $4.0 \mathrm{a}^{\mathrm{z}}$ & $9.5 \mathrm{a}$ & 30.0 & 1.6 & 30.0 & 0.6 \\
\hline & Rye-C & Rye & NA & NA & 44.1 & $3.5 \mathrm{~b}$ & $5.4 \mathrm{~b}$ & 46.7 & 6.3 & 26.7 & 3.1 \\
\hline & Cam-C & Camelina & NA & NA & 41.0 & $3.9 \mathrm{a}$ & $7.6 \mathrm{a}$ & 40.0 & 2.3 & 33.3 & 1.5 \\
\hline & Cam-C & Camelina & NA & NA & 40.3 & $4.0 \mathrm{a}$ & $7.7 \mathrm{a}$ & 56.7 & 2.2 & 46.7 & 1.3 \\
\hline & Rye-C & Rye & NA & NA & 43.7 & $3.5 \mathrm{~b}$ & $5.5 \mathrm{~b}$ & 26.7 & 4.4 & 6.7 & 1.3 \\
\hline & $P$ value & & & & 0.06 & $<0.01$ & $<0.01$ & 0.39 & 0.06 & 0.18 & 0.59 \\
\hline \multirow{6}{*}{2017} & NC-S/NC-C & $\mathrm{NC}$ & $\mathrm{NC}$ & NA & $20.6 \mathrm{c}$ & $3.0 \mathrm{a}$ & $5.5 \mathrm{a}$ & $0.0 \mathrm{~b}$ & $0.0 \mathrm{~b}$ & $0.0 \mathrm{~b}$ & 0.0 \\
\hline & Rye-S/Rye-C & Rye & Rye & NA & $21.5 \mathrm{bc}$ & $2.2 \mathrm{~b}$ & $3.7 \mathrm{~b}$ & $26.6 \mathrm{a}$ & $3.2 \mathrm{ab}$ & $20.2 \mathrm{ab}$ & 2.2 \\
\hline & Cam-S/Cam-C & Camelina & Camelina & NA & $22.7 \mathrm{ab}$ & $2.7 \mathrm{a}$ & $5.8 \mathrm{a}$ & $0.0 \mathrm{~b}$ & $0.0 \mathrm{c}$ & $0.0 \mathrm{~b}$ & 0.0 \\
\hline & Rye-S/Cam-C & Rye & Camelina & NA & $23.1 \mathrm{ab}$ & $2.8 \mathrm{a}$ & $5.8 \mathrm{a}$ & $6.8 \mathrm{~b}$ & $0.3 \mathrm{bc}$ & $3.4 \mathrm{~b}$ & 0.14 \\
\hline & Cam-S/Rye-C & Camelina & Rye & NA & $23.3 \mathrm{a}$ & $2.3 \mathrm{~b}$ & $4.3 \mathrm{~b}$ & $33.4 \mathrm{a}$ & $4.18 \mathrm{a}$ & $26.7 \mathrm{a}$ & 5.7 \\
\hline & $P$ value & & & & 0.02 & $<0.01$ & $<0.01$ & 0.01 & 0.03 & 0.05 & 0.17 \\
\hline \multirow[t]{6}{*}{2018} & NC-C/NC-S/NC-C & $\mathrm{NC}$ & $\mathrm{NC}$ & $\mathrm{NC}$ & 44.6 & $4.2 \mathrm{a}$ & $5.0 \mathrm{a}$ & $10.0 \mathrm{c}$ & 1.1 & 0.0 & 0.0 \\
\hline & Rye-C/Rye-S/Rye-C & Rye & Rye & Rye & 40.4 & $4.0 \mathrm{~b}$ & $2.7 \mathrm{c}$ & $56.7 \mathrm{ab}$ & 13.1 & 40.0 & 0.2 \\
\hline & Cam-C/Cam-S/Cam-C & Camelina & Camelina & Camelina & 41.5 & $4.4 \mathrm{a}$ & $3.8 \mathrm{~b}$ & $40.0 \mathrm{ab}$ & 6.7 & 30.0 & 0.2 \\
\hline & Cam-C/Rye-S/Cam-C & Camelina & Rye & Camelina & 42.0 & $4.3 \mathrm{a}$ & $4.0 \mathrm{~b}$ & $30.0 \mathrm{ab}$ & 6.7 & 23.3 & 0.1 \\
\hline & Rye-C/Cam-S/Rye-C & Rye & Camelina & Rye & 40.9 & $4.0 \mathrm{~b}$ & $2.8 \mathrm{c}$ & $60.0 \mathrm{a}$ & 12.2 & 26.7 & 0.1 \\
\hline & $P$ value & & & & 0.12 & $<0.01$ & $<0.01$ & 0.03 & 0.13 & 0.10 & 0.36 \\
\hline
\end{tabular}

s Abbreviations: $\mathrm{NC}=$ no cover crop; $\mathrm{Cam}=$ camelina; $\mathrm{C}=$ corn; and $\mathrm{S}=$ soybean.

t Corn shoot height was measured from ground level to the extended leaf in (6 June 2016, 25 May 2017, and 7 June 2018).

u Corn shoot was dried in an oven at $60^{\circ} \mathrm{C}$ and weighed.

$\checkmark$ Radicle root rot $(\mathrm{RR})$ incidence was calculated as the percentage of seedlings with lesions on the radicle $(N=30)$.

${ }^{w}$ Radicle RR index was calculated using the formula DX $=\mathrm{DI} \times \mathrm{DS} / 5$. Disease severity (DS) was scored on a 0 to 5 scale, where $1,2,3,4$, and $5=1$ to $10 \%, 11$ to $25 \%, 26$ to $50 \%, 51$ to $75 \%$, and 76 to $100 \%$ of roots covered with lesions, respectively. Healthy plants with no visible lesions were assigned a value of 0 . DI $=$ disease incidence, and DX $=$ disease index.

x Seminal RR incidence was calculated as the percentage of seedlings with lesions on the seminal roots $(N=30)$.

y Seminal RR index was calculated using the formula DX $=$ DI $\times$ DS $/ 5$.

$\mathrm{z}$ Values followed by the same letter within a column are not significantly different at $P$ value 0.05 . 
of barren plants were not different between treatments in all three study years (Table 10). The number of ears, however, was significantly different among treatments in both 2017 and $2018(P=$ 0.02 ). In 2017, both treatments in which corn followed rye had significantly fewer ears than the no cover crop control and the treatment in which camelina was planted every year (Cam-S/Cam-C). In 2018, the control and the two rye treatments had significantly fewer ears than one of the camelina treatments (Rye-S/Cam-C).

In general, for all three years, corn yields for at least one of the two treatments with a rye cover crop before corn were reduced compared with corn following a camelina cover crop or the no cover crop control $(P<0.01$; Table 10). Additionally, in general if there was a yield reduction of corn following camelina the magnitude was smaller than that caused by rye. Specifically, in 2016 one of the two rye before corn treatments had significantly lower yields than the control and the camelina treatments with no other differences among the other treatments. In 2017, the two rye treatments had significantly lower yields than other treatments, and the two camelina treatments had lower yields than the control treatment but greater than the rye treatments. Lastly, in 2018 the rye treatments had the lowest yields, whereas one of the two camelina treatments had lower yields than the control. Thus, using a camelina cover crop before corn improved corn yield compared with a rye cover crop before corn but still reduced yield relative to the control in some years. Planting a camelina cover crop every year had no consistent corn yield advantage over planting a rye cover crop before soybean and a camelina cover crop before corn.

Soybean yield and population. In general, neither soybean population nor yield were negatively affected by the cover crop treatments relative to the no cover crop control (Table 11). Soybean populations at physiological maturity in the no cover crop treatments were lower than one or more of the other cover crop treatments in 2016 and 2018. In 2016, the control had fewer plants than the two treatments with a camelina cover crop preceding soybean. In 2018, soybean following rye with camelina preceding corn in the previous year had higher populations than the control. In 2017, the two treatments in which rye preceded soybean had significantly greater yields than the control and the treatment in which a camelina cover crop was planted before both corn and soybean.

\section{Discussion}

This research evaluated the effect of a grass (winter cereal rye) and broadleaf (camelina) cover crop on corn and soybean seedling growth and development, root rot, and yield measurements over a 3 -year study period. Both cash crops were grown in rotation and were present in each year of the study. In general, planting corn after a cover crop of camelina improved corn growth and development, reduced corn root rot, and increased the yield of corn compared with planting corn after a cover crop of winter cereal rye, regardless of the cover crop before soybean in the previous spring. Thus, for these two cover crop species, the cover crop preceding the corn crop is more important than the cover crop species in the previous spring. In general, neither of these cover crop species immediately preceding soybean had a consistent negative effect on soybean growth and development, root rot, and yield.

Cover crop stand counts for both cover crop species were greater following soybean compared with stands following corn, probably because of the later planting dates after corn and greater corn residue. Soybean harvest occurred 2 to 3 weeks prior to corn harvest, and thus

Table 8. Density of Pythium spp. belonging to clade B and clade F in radicles of corn seedlings sampled in 2017 and 2018 and mesocotyls sampled in 2017 from field experiments in Iowa ${ }^{x}$

\begin{tabular}{llccccc}
\hline & & \multicolumn{2}{c}{ Radicle root } & & \multicolumn{2}{c}{ Mesocotyl } \\
\cline { 3 - 4 } \cline { 6 - 7 } Year & \multicolumn{1}{c}{ Treatments } & Clade B & Clade F & & Clade B & Clade F \\
\hline 2017 & NC-S/NC-C & $0.54 \mathrm{c}^{\mathrm{z}}$ & $0.12 \mathrm{~b}$ & & 0.48 & $0.18 \mathrm{~b}$ \\
& Rye-S/Rye-C & $1.50 \mathrm{a}$ & $0.00 \mathrm{~b}$ & & 1.19 & $0.00 \mathrm{~b}$ \\
& Cam-S/Cam-C & $0.70 \mathrm{bc}$ & $0.83 \mathrm{a}$ & & 0.39 & $0.67 \mathrm{a}$ \\
& Rye-S/Cam-C & $1.17 \mathrm{ab}$ & $0.21 \mathrm{~b}$ & & 0.37 & $0.10 \mathrm{~b}$ \\
& Cam-S/Rye-C & $1.76 \mathrm{a}$ & $0.19 \mathrm{~b}$ & & 0.61 & $0.47 \mathrm{ab}$ \\
& $P$ value & $<0.01$ & $<0.01$ & & 0.22 & $<0.01$ \\
& NC-C/NC-S/NC-C & 0.00 & $0.00 \mathrm{~b}$ & & - & - \\
& Rye-C/Rye-S/Rye-C & 0.68 & $0.00 \mathrm{~b}$ & & - \\
& Cam-C/Cam-S/Cam-C & 0.21 & $0.13 \mathrm{~b}$ & & - \\
& Cam-C/Rye-S/Cam-C & 0.61 & $0.59 \mathrm{a}$ & & - & - \\
& Rye-C/Cam-S/Rye-C & 0.38 & $0.00 \mathrm{~b}$ & & - & - \\
& $P$ value & 0.14 & $<0.01$ & & - & - \\
\hline
\end{tabular}

${ }^{x}$ Density is expressed as copies of Pythium ITS gene per million copies of the $\alpha$-tubulin (tua4) gene for corn, $\log _{10}$ transformed.

y Abbreviations: $\mathrm{NC}=$ no cover crop; $\mathrm{Cam}=$ camelina; $\mathrm{C}=$ corn; and $\mathrm{S}=$ soybean.

${ }^{\mathrm{z}}$ Values followed by the same letter within a column are not significantly different at $P$ value 0.05 .

Table 7. Average effects of cover crop treatments on soybean seedling growth at growth stage V4 to V5 in field experiments in Iowa ${ }^{\mathrm{v}}$

\begin{tabular}{|c|c|c|c|c|c|c|c|}
\hline Year & Treatments $^{w}$ & $\begin{array}{l}\text { Cover crop } \\
\text { Fall } 2015\end{array}$ & $\begin{array}{c}\text { Cover crop } \\
\text { Fall } 2016\end{array}$ & $\begin{array}{c}\text { Cover crop } \\
\text { Fall } 2017\end{array}$ & 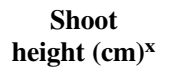 & Leaf stage & $\begin{array}{r}\text { Shoot dry } \\
\text { weight }(g)^{y}\end{array}$ \\
\hline \multirow[t]{6}{*}{$\overline{2016}$} & NC-S & $\mathrm{NC}$ & NA & NA & 11.1 & 2.8 & $3.3 \mathrm{a}^{\mathrm{z}}$ \\
\hline & Rye-S & Rye & NA & NA & 11.7 & 2.5 & $2.8 \mathrm{a}$ \\
\hline & Cam-S & Camelina & NA & NA & 11.5 & 2.6 & $3.1 \mathrm{a}$ \\
\hline & Cam-S & Camelina & NA & NA & 10.8 & 2.6 & $3.0 \mathrm{a}$ \\
\hline & Rye-S & Rye & NA & NA & 11.3 & 2.4 & $2.0 \mathrm{~b}$ \\
\hline & $P$ value & & & & 0.48 & 0.13 & 0.02 \\
\hline \multirow[t]{6}{*}{2017} & NC-C/NC-S & $\mathrm{NC}$ & $\mathrm{NC}$ & NA & $15.9 \mathrm{c}$ & 2.2 & 2.2 \\
\hline & Rye-C/Rye-S & Rye & Rye & NA & $17.3 \mathrm{ab}$ & 2.2 & 2.3 \\
\hline & Cam-C/Cam-S & Camelina & Camelina & NA & $16.3 \mathrm{bc}$ & 2.2 & 2.1 \\
\hline & Rye-C/Cam-S & Rye & Camelina & NA & $16.5 \mathrm{bc}$ & 2.2 & 2.4 \\
\hline & Cam-C/Rye-S & Camelina & Rye & NA & $17.8 \mathrm{a}$ & 2.3 & 2.3 \\
\hline & $P$ value & & & & 0.02 & 0.98 & 0.56 \\
\hline \multirow[t]{6}{*}{2018} & NC-S/NC-C/NC-S & $\mathrm{NC}$ & $\mathrm{NC}$ & $\mathrm{NC}$ & 34.7 & $4.8 \mathrm{a}$ & $4.9 \mathrm{a}$ \\
\hline & Rye-S/Rye-C/Rye-S & Rye & Rye & Rye & 32.3 & $4.3 \mathrm{~b}$ & $4.0 \mathrm{~b}$ \\
\hline & Cam-S/Cam-C/Cam-S & Camelina & Camelina & Camelina & 32.4 & $4.9 \mathrm{a}$ & $4.9 \mathrm{a}$ \\
\hline & Cam-S/Rye-C/Cam-S & Camelina & Rye & Camelina & 33.4 & $5.0 \mathrm{a}$ & $4.7 \mathrm{a}$ \\
\hline & Rye-S/Cam-C/Rye-S & Rye & Camelina & Rye & 31.1 & $4.1 \mathrm{~b}$ & $3.8 \mathrm{~b}$ \\
\hline & $P$ value & & & & 0.15 & $<0.01$ & $<0.01$ \\
\hline
\end{tabular}

\footnotetext{
$\checkmark$ Note: disease data from soybean seedlings were not presented in the table due to minimal disease recorded after each cover crop treatment.

w Abbreviations: $\mathrm{NC}=$ no cover crop; $\mathrm{Cam}=$ camelina; $\mathrm{C}=$ corn; and $\mathrm{S}=$ soybean.

x Soybean shoot height was measured from ground level to the tip of the apical meristem in (13 June 2016, 12 June 2017, and 18 June 2018 ).

y Soybean shoot was dried in an oven at $60^{\circ} \mathrm{C}$ and weighed.

z Values followed by the same letter within a column are not significantly different at $P$ value 0.05 .
} 
the cover crops were planted following soybean 3 to 4 weeks before those planted following corn, allowing better establishment and growth in the fall. In addition, surface crop residue levels differed considerably between corn and soybean plots. More shoot residue is left on the ground after corn harvest compared with that after soybean harvest (Buyanovsky and Wagner 1986). Because high amounts of surface crop residue reduce drill performance, planting depth, and cover crop seed contact with the soil, establishment of the cover crop can be reduced (Benedict et al. 2014).

In this study, rye shoot biomass production in spring was much greater in 2016 and 2017 compared with 2018. In fact, rye biomass production in 2018 was unusually low, probably because of the record low air temperatures that occurred in March and April, which is when most cover crop growth normally occurs in the upper Midwest. In contrast, camelina production was greatest in 2017 and lowest in 2018 and 2016. In all three years, a rye cover crop produced greater biomass than a camelina cover crop. A cereal rye cover crop

Table 9. Density of Pythium spp. belonging to clade B and clade F in taproot and hypocotyl of soybean seedlings in different cover crop treatments sampled from field experiments in 2017 and $2018^{x}$

\begin{tabular}{clccccc}
\hline & & \multicolumn{2}{c}{ Taproot } & & \multicolumn{2}{c}{ Hypocotyl } \\
\cline { 3 - 4 } \cline { 6 - 7 } Year & \multicolumn{1}{c}{ Treatments $^{\mathbf{y}}$} & Clade B & Clade F & & Clade B & Clade F \\
\hline 2017 & NC-C/NC-S & 0.00 & 0.59 & & 0.07 & $0.03 \mathrm{~b}^{\mathbf{z}}$ \\
& Rye-C/Rye-S & 0.07 & 0.59 & & 0.00 & $0.24 \mathrm{~b}$ \\
& Cam-C/Cam-S & 0.00 & 1.28 & & 0.05 & $1.06 \mathrm{a}$ \\
& Rye-C/Cam-S & 0.00 & 0.85 & & 0.25 & $0.36 \mathrm{~b}$ \\
& Cam-C/Rye-S & 0.00 & 0.67 & & 0.17 & $0.00 \mathrm{~b}$ \\
& $P$ value & 0.38 & 0.16 & & 0.47 & $<0.01$ \\
& NC-S/NC-C/NC-S & 0.27 & 0.91 & & 0.00 & 0.06 \\
& Rye-S/Rye-C/Rye-S & 0.20 & 0.58 & & 0.00 & 0.00 \\
& Cam-S/Cam-C/Cam-S & 0.14 & 1.22 & & 0.77 & 0.35 \\
& Cam-S/Rye-C/Cam-S & 0.03 & 0.78 & & 0.77 & 0.00 \\
& Rye-S/Cam-C/Rye-S & 0.00 & 1.26 & & 0.00 & 0.28 \\
& $P$ value & 0.43 & 0.36 & & 0.57 & 0.19 \\
\hline
\end{tabular}

${ }^{x}$ Density is expressed as copies of Pythium ITS gene per million copies of the cyclophilin (CYP2) gene for soybean, $\log _{10}$ transformed.

y Abbreviations: $\mathrm{NC}=$ no cover $\mathrm{crop}$; $\mathrm{Cam}=$ camelina; $\mathrm{C}=$ corn; and $\mathrm{S}=$ soybean.

${ }^{z}$ Values followed by the same letter within a column are not significantly different at $P$ value 0.05 . has excellent winter hardiness even when planted late in the fall, grows well at cool temperatures, and begins growing early in the spring (Snapp et al. 2005). There have not been many studies on the use of camelina as a cover crop or on its growth characteristics in the upper Midwest (Appelgate et al. 2017; Berti et al. 2017). It is possible that camelina would produce more shoot biomass relative to rye if it was managed differently than it was in this study (e.g., planted earlier, different seeding method, or a higher seeding rate). In general, many farmers prefer to have high biomass production by cover crops in the spring because they associate this with healthier soils, as more aboveground biomass indicates greater below ground (root) biomass that positively affects soil health (Bodner et al. 2010; Schutter and Dick 2002). The amount of biomass produced by cover crops is also strongly correlated to their water and nitrogen uptake (Sinclair and Rufty 2012) and erosion protection (Kaspar et al. 2001) and consequently has positive environmental implications. Nonetheless, even though camelina does not produce as much shoot biomass as a cereal rye cover crop, there may be other advantages that may compensate for the lower biomass production.

In the current study, we generally observed less root rot on corn radicle and seminal tissues in 2017 and 2018 when camelina was used as a cover crop before corn rather than rye. No difference in corn root rot between treatments in 2016, the first year of the study, could be due to high background levels of soil pathogens, as indicated by the root rot incidence in the $\mathrm{NC}-\mathrm{C}$ treatment. It could also be because this was the first year that cover crop treatments were established for the trial.

Not surprisingly, cereal rye, a grass species like corn, hosts corn pathogens (Bakker et al. 2016). Cereal rye, therefore, may act as a green bridge (i.e., provides a host over the winter fallow period) when it is used as a cover crop before corn (Acharya et al. 2017). It is not known what corn seedling pathogens survive on camelina, although root rot caused by Pythium sylvaticum and Fusarium graminearum has been observed (Araldi Da Silva 2019). It is possible that camelina does not host many corn pathogens or that the corn pathogens it hosts are not extremely aggressive. Consequently, a cover crop rotation of camelina before corn and cereal rye before soybean may reduce the population of specific soil-borne corn pathogens (Supplementary Table 1). However, decreasing some pathogen populations in the soil may require longer periods without a host species to become apparent.

In our study, Pythium clade B was prevalent in corn radicle tissues particularly following rye, with a tendency for reduced numbers

Table 10. Average final plant stand, number of barren plants, number of ears, and yield of corn following cover crop treatments in field experiments in Iowa

\begin{tabular}{|c|c|c|c|c|c|c|c|c|}
\hline Year & Treatments $^{x}$ & $\begin{array}{c}\text { Cover crop } \\
\text { Fall } 2015\end{array}$ & $\begin{array}{c}\text { Cover crop } \\
\text { Fall } 2016\end{array}$ & $\begin{array}{c}\text { Cover crop } \\
\text { Fall } 2017\end{array}$ & $\begin{array}{c}\text { Mature } \\
\text { plants/ha }\end{array}$ & Barren/ha & Ears/ha & $\begin{array}{c}\text { Yield } \\
(\mathrm{Mg} / \mathrm{ha})^{y}\end{array}$ \\
\hline \multirow[t]{6}{*}{2016} & $\mathrm{NC}-\mathrm{C}$ & $\mathrm{NC}$ & NA & NA & 84,927 & 1,004 & 83,922 & $12.6 \mathrm{ab}^{\mathrm{z}}$ \\
\hline & Rye-C & Rye & NA & NA & 83,635 & 1,004 & 82,631 & $10.6 \mathrm{c}$ \\
\hline & Cam-C & Camelina & NA & NA & 80,336 & 1,004 & 79,332 & $12.8 \mathrm{a}$ \\
\hline & Cam-C & Camelina & NA & NA & 82,057 & 1,147 & 80,909 & $12.3 \mathrm{ab}$ \\
\hline & Rye-C & Rye & NA & NA & 80,623 & 861 & 79,762 & $11.4 \mathrm{bc}$ \\
\hline & $P$ value & & & & 0.87 & 0.99 & 0.89 & 0.01 \\
\hline \multirow[t]{6}{*}{2017} & NC-S/NC-C & $\mathrm{NC}$ & $\mathrm{NC}$ & NA & 80,336 & 1,435 & $78,901 \mathrm{a}$ & $11.5 \mathrm{a}$ \\
\hline & Rye-S/Rye-C & Rye & Rye & NA & 76,463 & 3,299 & $73,163 \mathrm{c}$ & $8.4 \mathrm{c}$ \\
\hline & Cam-S/Cam-C & Camelina & Camelina & NA & 80,766 & 2,009 & $78,758 \mathrm{a}$ & $10.0 \mathrm{~b}$ \\
\hline & Rye-S/Cam-C & Rye & Camelina & NA & 80,336 & 2,439 & $77,897 \mathrm{ab}$ & $10.0 \mathrm{~b}$ \\
\hline & Cam-S/Rye-C & Camelina & Rye & NA & 77,754 & 3,730 & $74,024 \mathrm{bc}$ & $8.6 \mathrm{c}$ \\
\hline & $P$ value & & & & 0.15 & 0.11 & 0.02 & $<0.01$ \\
\hline \multirow[t]{6}{*}{2018} & NC-C/NC-S/NC-C & $\mathrm{NC}$ & $\mathrm{NC}$ & $\mathrm{NC}$ & 77,180 & 861 & $76,319 \mathrm{c}$ & $13.3 \mathrm{a}$ \\
\hline & Rye-C/Rye-S/Rye-C & Rye & Rye & Rye & 78,901 & 1,435 & $77,467 \mathrm{bc}$ & $10.1 \mathrm{c}$ \\
\hline & Cam-C/Cam-S/Cam-C & Camelina & Camelina & Camelina & 81,914 & 1,004 & $80,909 \mathrm{ab}$ & $12.5 \mathrm{ab}$ \\
\hline & Cam-C/Rye-S/Cam-C & Camelina & Rye & Camelina & 81,914 & 574 & $81,340 \mathrm{a}$ & $12.2 \mathrm{~b}$ \\
\hline & Rye-C/Cam-S/Rye-C & Rye & Camelina & Rye & 79,188 & 2,009 & $77,180 \mathrm{c}$ & $10.8 \mathrm{c}$ \\
\hline & $P$ value & & & & 0.08 & 0.13 & 0.03 & $<0.01$ \\
\hline
\end{tabular}

x Abbreviations: $\mathrm{NC}=$ no cover crop; $\mathrm{Cam}=$ camelina; $\mathrm{C}=$ corn; and $\mathrm{S}=$ soybean.

${ }^{y}$ Corn yield data were collected from the middle three rows of each plot.

${ }^{\mathrm{z}}$ Values followed by the same letter within a column are not significantly different at $P$ value 0.05 . 
following a camelina cover crop. In contrast, although Pythium clade $\mathrm{F}$ was detected, albeit at reduced numbers compared with clade $\mathrm{B}$, density of clade $\mathrm{F}$ tended to be higher when corn followed camelina. These data are similar to data that we have reported before that indicated that Pythium clade B is dominant relative to clade $\mathrm{F}$ in corn roots that follow a rye cover crop (Acharya et al. 2017; Schenck et al. 2017). In preliminary research investigating populations of Pythium clade B and clade F in rye roots immediately prior to termination in 2017, we detected 100- to 1,000-fold more DNA of clade B in rye compared with clade F (Supplementary Table 1). Moreover, we detected 10- to 100-fold more DNA of clade F in the roots of camelina. Thus, these data further support our findings that a rye winter cover crop acts a green bridge for Pythium that infect corn. Interestingly, in the taproot of soybean, we detected clade $\mathrm{F}$ almost exclusively, and the preceding cover crop seemed to have had little effect. Further investigation is needed, however, to more fully understand the particular Pythium species involved in this system and their relative pathogenicity, particularly because species from both clades have been recovered from diseased corn and soybean seedlings and rye in the Midwest (Bakker et al. 2016; Matthiesen et al. 2016).

Similar to earlier reports (Acharya et al. 2018), we also detected almost equal densities of Pythium clade B members from mesocotyl tissue as from the radicle, although we observed minimal mesocotyl rot. As we have suggested before, we may be detecting latent or very early stage infection in the mesocotyl, which emerges later than the radicle, due to difference in time since these tissues were exposed to the soil microbial environment (Acharya et al. 2018). Similarly, in soybean hypocotyl tissues, we detected similar densities of Pythium from both clades, but no hypocotyl rot was observed.

We detected reduced corn yield following a rye cover crop compared with no cover crop in all three years. The reduced yields in 2017 for the rye cover crop plots were partly a consequence of fewer ears produced, which was combination of fewer plants and more barren plants. In 2016 and 2018, it was not likely that fewer ears caused the reduction in yield, and we hypothesize that grain weight per ear was most likely less in the rye treatments. We did not, however, collect data on ear size or grain weight per ear, so we are unable to confirm that these factors contributed to the yield decrease. Greater seedling root disease and reduced corn seedling growth were evident following a rye cover crop. The relatively larger density of Pythium clade B infecting corn radicles after rye in 2017 and 2018, also correspond with the greater corn yield reduction (intercept $=-5.00$, slope $=18.5$, and $R^{2}=0.847$ in 2017 ; intercept $=1.53$, slope $=$ 26.3 , and $R^{2}=0.571$ in 2018). Other studies have shown that seedling disease in corn may reduce stand, delay emergence, or reduce plant vigor (Acharya et al. 2017; Munkvold 1999) and consequently contribute to reduced yields due to decreased stands, more barren plants, or plants with smaller ears (Acharya et al. 2017; Buren et al. 1974; Nafziger et al. 1991; Smith et al. 1982).

Although planting a camelina cover crop before corn reduced seedling disease and increased yield compared with planting a rye cover crop before corn, yields were still significantly lower than yields of corn in the no cover crop control plots in two of the three years. This is in spite of very little evidence of increased seedling disease relative to the control of corn planted following a camelina cover crop. It is possible that camelina, like rye, may have reduced nitrogen availability for the corn seedlings, but this seems like less of a possibility for camelina than rye because of much lower camelina shoot biomass production. As mentioned earlier, the use of camelina as a cover crop is relatively new, so improved management may help to prevent even these small corn yield decreases.

As mentioned above, many possible reasons have been proposed for reduced corn yield following a rye winter cover crop. One possible mechanism is that the reduced yield of corn in our rye cover crop treatments may have been related to nitrogen dynamics or availability. We detected greater nitrogen in rye shoot biomass, which possibly could have limited the soil nitrogen and have influenced the growth of the following cash crop. The role of nitrogen fertilizer in corn production is well known (Stewart et al. 2005). Pantoja et al. (2015) reported a cereal rye cover crop in a corn-soybean cropping system reduced soil nitrogen availability for the corn crop due to cover crop uptake of soil nitrogen in the spring prior to corn planting. Kaspar et al. (2007) showed rye cover crop shoot nitrogen and, therefore, uptake generally increased as shoot biomass increased. Additionally, decomposition of cover crop shoot and root residues may have immobilized nitrogen soon after corn planting (Karlen and Doran 1991; Tollenaar et al. 1993; Wagger and Mengel 1993). Lastly, nitrogen availability can also be limited by slow or restricted root growth (Lynch 2013). Because we showed increased root infection following a rye cover crop, it is likely that root extension was also reduced, thus limiting access to soil nitrogen. Greater availability of nitrogen early in the growing season may have resulted in higher yields for rye cover crop treatments because of more vigorous early seedling growth. Further research is required to understand the interaction between rye cover crop nitrogen uptake, rye residue decomposition, and seedling root disease inhibition of root extension.

No negative effect of either rye or camelina cover crops on soybean seedling disease, seedling growth, population, and yield were

Table 11. Average number of plants and yield of soybean following cover crop treatments in field experiments in Iowa

\begin{tabular}{|c|c|c|c|c|c|c|}
\hline Year & Treatments $^{x}$ & Cover crop Fall 2015 & Cover crop Fall 2016 & Cover crop Fall 2017 & Population/ha & Yield $(\mathrm{Ma} / \mathrm{ha})^{\mathrm{y}}$ \\
\hline \multirow[t]{6}{*}{2016} & NC-S & $\mathrm{NC}$ & NA & NA & $186,402 \mathrm{c}^{\mathrm{z}}$ & 2.7 \\
\hline & Rye-S & Rye & NA & NA & $258,328 \mathrm{ab}$ & 2.4 \\
\hline & Cam-S & Camelina & NA & NA & 290,239 a & 2.5 \\
\hline & Cam-S & Camelina & NA & NA & $208,689 \mathrm{bc}$ & 2.4 \\
\hline & Rye-S & Rye & NA & NA & $269,472 \mathrm{a}$ & 2.5 \\
\hline & $P$ value & & & & $<0.01$ & 0.43 \\
\hline \multirow[t]{6}{*}{2017} & NC-C/NC-S & $\mathrm{NC}$ & $\mathrm{NC}$ & NA & 279,602 & $2.2 \mathrm{~b}$ \\
\hline & Rye-C/Rye-S & Rye & Rye & NA & 309,994 & $2.5 \mathrm{a}$ \\
\hline & Cam-C/Cam-S & Camelina & Camelina & NA & 232,495 & $2.2 \mathrm{~b}$ \\
\hline & Rye-C/Cam-S & Rye & Camelina & NA & 275,550 & $2.4 \mathrm{ab}$ \\
\hline & Cam-C/Rye-S & Camelina & Rye & NA & 299,357 & $2.5 \mathrm{a}$ \\
\hline & $P$ value & & & & 0.09 & 0.03 \\
\hline \multirow[t]{6}{*}{2018} & NC-S/NC-C/NC-S & $\mathrm{NC}$ & $\mathrm{NC}$ & $\mathrm{NC}$ & 203,792 b & 3.7 \\
\hline & Rye-S/Rye-C/Rye-S & Rye & Rye & Rye & $225,033 \mathrm{ab}$ & 3.7 \\
\hline & Cam-S/Cam-C/Cam-S & Camelina & Camelina & Camelina & $217,139 a b$ & 3.7 \\
\hline & Cam-S/Rye-C/Cam-S & Camelina & Rye & Camelina & $219,435 \mathrm{~b}$ & 3.8 \\
\hline & Rye-S/Cam-C/Rye-S & Rye & Camelina & Rye & 241,537 a & 3.7 \\
\hline & $P$ value & & & & 0.035 & 0.94 \\
\hline
\end{tabular}

\footnotetext{
${ }^{\mathrm{x}}$ Abbreviations: $\mathrm{NC}=$ no cover crop; $\mathrm{Cam}=$ camelina $\mathrm{C}=$ corn; and $\mathrm{S}=$ soybean.

y Soybean yield data were obtained from the entire five-row plot.

${ }^{\mathrm{z}}$ Values followed by the same letter within a column are not significantly different at $P$ value 0.05 .
} 
detected in this study. This result supports previous findings in which a positive or no effect of cover crops on soybean yield was detected (Pantoja et al. 2015; Ruffo et al. 2004; Wen et al. 2017). It is unclear why no significant root rot or seedling disease was observed in soybean following rye in this current study, because rye is known to host species of both Pythium and Fusarium that are reported as pathogenic to soybeans (Bakker et al. 2016; Broders et al. 2007a, 2007b; Matthiesen et al. 2016). It may be due to the difference in planting dates of corn and soybean that relates to a difference in soil temperature at planting of each cash crop. Temperature affects the pathogenicity of Pythium spp. (Matthiesen et al. 2016). Moreover, Pythium spp. belonging to clade $\mathrm{B}$ were more pathogenic on corn and soybean at cooler temperatures $\left(13^{\circ} \mathrm{C}\right)$ than species belonging to clade $\mathrm{F}$, which caused more root rot on both crops at warmer temperatures $\left(23^{\circ} \mathrm{C}\right)$ (Matthiesen et al. 2016). Our previous work reported Pythium clade B was most likely the cause of corn root rot after a rye cover crop (Acharya et al. 2017). In this experiment, corn was planted 1 to 2 weeks before soybeans were planted, when soil temperatures are usually much cooler. Interestingly, in this current study we detected minimal Pythium clade B in soybean roots. We have no explanation, especially because previous work from our laboratory reported no difference in the susceptibility of both corn and soybean to species from Pythium clade B (Matthiesen et al. 2016).

Based on the results from this study, using a winter-hardy brassica, such as camelina, as a cover crop after soybean and before corn could be a potential management option to reduce seedling disease in corn and to contribute the sustainability of the corn-soybean production system in the Midwest by including a cover crop before both corn and soybean. Unfortunately, camelina seed is not widely available at this time, and more needs to be learned about managing it as a cover crop. Winter cereal rye is likely to remain a staple cover crop in the Midwest because it is relatively inexpensive, usually available as seed, overwinters, and, perhaps most importantly, grows well between corn and soybean harvest and planting. Because rye has no deleterious effects on soybean, using it as a cover crop before soybean is easier and requires less management. Thus, rye cover crops before soybean are being encouraged as a beginning practice for farmers to increase cover crops on the Iowa landscape and contribute to goals laid out in the Iowa Nutrient Reduction Strategy (J. Benning, personal communication). Still, a further understanding of the factors that contribute to seedling disease that develops on corn seedlings following cereal rye should allow us to develop strategies such as fungicide treatments, early termination of the cover crop, or precision planting of rye cover crops in the interrow to reduce the negative effect of rye on corn. With continued research and increases in camelina seed availability, we expect that using a camelina cover crop before corn and cereal rye before soybean will have the potential to be a viable cover crop system for the upper Midwest.

\section{Acknowledgments}

We thank K. Kohler for establishing and managing the field trial.

\section{Literature Cited}

Abendroth, L. J., Elmore, R. W., Boyer, M. J., and Marlay, S. K. 2011. Corn Growth and Development. PMR 1009. Iowa State University Extension and Outreach, Ames, IA.

Acharya, J., Bakker, M. G., Moorman, T. B., Kaspar, T. C., Lenssen, A. W., and Robertson, A. E. 2017. Time interval between cover crop termination and planting influences corn seedling disease, plant growth, and yield. Plant Dis. 101:591-600.

Acharya, J., Bakker, M. G., Moorman, T. B., Kaspar, T. C., Lenssen, A. W., and Robertson, A. E. 2018. Effects of fungicide seed treatments and a winter cereal rye cover crop in no till on the seedling disease complex in corn. Can. J. Plant Pathol. 40:481-497.

Appelgate, S., Lenssen, A. W., Wiedenhoeft, M., and Kaspar, T. 2017. Cover crop options and mixes for upper Midwest corn-soybean systems. Agron. J. 109:968-984.

Araldi Da Silva, G. D. 2019. Studies on the impact of cover crops on soybean productivity and root diseases. Ph.D. thesis. Iowa State University, Ames, IA.

Bakker, M. G., Acharya, J., Moorman, T. B., Robertson, A. E., and Kaspar, T. C. 2016. The potential for cereal rye cover crops to host corn seedling pathogens. Phytopathology 106:591-601.

Bakker, M. G., Moorman, T. B., Kaspar, T. C., and Manter, D. K. 2017. Isolation of cultivation-resistant oomycetes, first detected as amplicon sequences, from roots of herbicide-terminated winter rye. Phytobiomes 1:24-35.
Basche, A. D., Archontoulis, S. V., Kaspar, T. C., Jaynes, D. B., Parkin, T. B., and Miguez, F. E. 2016. Simulating long-term impacts of cover crops and climate change on crop production and environmental outcomes in the Midwestern United States. Agric. Ecosyst. Environ. 218:95-106.

Benedict, C., Cogger, C., and Andrews, N. 2014. Methods for Successful Cover Crop Management in Your Home Garden. Washington State University Extension, Pullman, WA.

Berti, M. T., Samarappuli, D., Johnson, B. L., and Gesch, R. W. 2017. Integrating winter camelina into maize and soybean cropping systems. Ind. Crops Prod. 107:595-601.

Bodner, G., Himmelbauer, M., Loiskandl, W., and Kaul, H. P. 2010. Improved evaluation of cover crop species by growth and root factors. Agron. Sustain. Dev. 30:455-464.

Bradley, C. A. 2008. Effect of fungicide seed treatments on stand establishment, seedling disease, and yield of soybean in North Dakota. Plant Dis. 92:120-125.

Broders, K. D., Lipps, P. E., Paul, P. A., and Dorrance, A. E. 2007a Characterization of Pythium spp. associated with corn and soybean seed and seedling disease in Ohio. Plant Dis. 91:727-735.

Broders, K. D., Lipps, P. E., Paul, P. A., and Dorrance, A. E. 2007b. Evaluation of Fusarium graminearum associated with corn and soybean seed and seedling disease in Ohio. Plant Dis. 91:1155-1160.

Buren, L. L., Mock, J. J., and Anderson, I. C. 1974. Morphological and physiological traits in maize associated with tolerance to high plant density. Crop Sci. 14:426-429.

Buyanovsky, G. A., and Wagner, G. H. 1986. Post-harvest residue input to cropland. Plant Soil 93:57-65.

Carpenter, A., and Board, J. 1997a. Branch yield components controlling soybean yield stability across plant populations. Crop Sci. 37:885-891.

Carpenter, A., and Board, J. 1997b. Growth dynamic factors controlling soybean yield stability across plant populations. Crop Sci. 37:1520-1526.

Colvin, T. S. 1990. Automated weighing and moisture sampling for a field plot combine. Appl. Eng. Agric. 6:713-714.

Cox, W., and Cherney, J. H. 2011. Growth and yield responses of soybean to row spacing and seeding rate. Agron. J. 103:123-128.

Ding, G., Liu, X., Herbert, S., Novak, J., Amarasiriwardena, D., and Xing, B. 2006 Effect of cover crop management on soil organic matter. Geoderma 130:229-239.

Duiker, S. W., and Curran, W. S. 2005. Rye cover crop management for corn production in the northern mid-Atlantic region. Agron. J. 97:1413-1418.

Gesch, R. W., and Cermak, S. C. 2011. Sowing date and tillage effects on fallseeded camelina in the northern Corn Belt. Agron. J. 103:980-987.

Iowa Department of Agriculture and Land Stewardship. 2013. Iowa Nutrient Reduction Strategy. Iowa Department of Agriculture and Land Stewardship, Des Moines, IA.

Jian, B., Liu, B., Yurong, B., Wensheng, H., Cunxiang, W., and Han, T. 2008 Validation of internal control for gene expression study in soybean by quantitative real-time PCR. BMC Mol. Biol. 9:59.

Kandel, Y. R., Bradley, C. A., Wise, K. A., Chilvers, M. I., Tenuta, A. U., Davis, V. M., Esker, P. D., Smith, D. L., Licht, M. A., and Mueller, D. S. 2015. Effect of glyphosate application on sudden death syndrome of glyphosate-resistant soybean under field conditions. Plant Dis. 99:347-354.

Karlen, D. L., and Doran, J. W. 1991. Cover crop management effects on soybean and corn growth and nitrogen dynamics in an on-farm study. Am. J. Altern. Agric. 6:71-82.

Kaspar, T. C., and Bakker, M. G. 2015. Biomass production of 12 winter cereal cover crop cultivars and their effect on subsequent no-till corn yield. J. Soil Water Conserv. 70:353-364.

Kaspar, T. C., Jaynes, D. B., Parkin, T. B., and Moorman, T. B. 2007. Rye cover crop and gamagrass strip effects on $\mathrm{NO}_{3}$ concentration and load in tile drainage. J. Environ. Qual. 36:1503-1511.

Kaspar, T. C., Radke, J. K., and Laflen, J. M. 2001. Small grain cover crops and wheel traffic effects on infiltration, runoff, and erosion. J. Soil Water Conserv. 56:160-164.

Kessavalou, A., and Walters, D. T. 1997. Winter rye as a cover crop following soybean under conservation tillage. Agron. J. 89:68-74.

Larkin, R. P., Griffin, T. S., and Honeycutt, C. W. 2010. Rotation of cover crop effects on soilborne potato diseases, tuber yield, and soil microbial communities. Plant Dis. 94:1491-1502.

Li, S. J., Zhu, T. H., Zhu, H. M. Y., Liang, M., Qiao, T. M., Han, S., and Che, G. N 2013. Purification of protein AP-toxin from Arthrinium phaeospermum causing blight in Bambusa pervariabilis $\times$ Dendro-calamopisis grandis and its metabolic effects on four bamboo varieties. Phytopathology 103:135-145.

Lynch, J. P. 2013. Steep, cheap and deep: An ideotype to optimize water and N acquisition by maize root systems. Ann. Bot. 112:347-357.

Matthiesen, R. L., Ahmad, A. A., and Robertson, A. E. 2016. Temperature affects aggressiveness and fungicide sensitivity of four Pythium spp. that cause soybean and corn damping off in Iowa. Plant Dis. 100:583-591.

Mideros, S. X., Windham, G. L., Williams, W. P., and Nelson, R. J. 2009 Aspergillus flavus biomass in maize estimated by quantitative real-time polymerase chain reaction is strongly correlated with aflatoxin concentration. Plant Dis. 93:1163-1170.

Miguez, F. E., and Bollero, G. A. 2005. Review of corn yield response under winter cover cropping systems using meta-analytic methods. Crop Sci. 45 2318-2329. 
Moore, E. B., Wiedenhoeft, M. H., Kaspar, T. C., and Cambardella, C. A. 2014. Rye cover crop effects on soil quality in no-till corn silage-soybean cropping systems. Soil Sci. Soc. Am. J. 78:968-976.

Munawar, A., Blevins, R. L., Frye, W. W., and Saul, M. R. 1990. Tillage and cover crop management for soil water conservation. Agron. J. 82:773-777.

Munkvold, G. P. 1999. Corn seedling diseases causing problems. Online publication. Iowa State University Integrated Crop Management News 2156. https://lib.dr.iastate.edu/cropnews/2156/

Nafziger, E. D., Carter, P. R., and Graham, E. E. 1991. Response of corn to uneven emergence. Crop Sci. 31:811-815.

National Agricultural Statistics Service (NASS). 2017. Census of Agriculture, County Level Data: Iowa. https://www.nass.usda.gov/Publications/AgCensus/ 2017/Full_Report/Volume_1,_Chapter_2_County_Level/Iowa/st19_2_0041_ 0041.pdf.

Pantoja, J. L., Woli, K. P., Sawyer, J. E., and Barker, D. W. 2015. Corn nitrogen fertilization requirement and corn-soybean productivity with a rye cover crop. Soil Sci. Soc. Am. J. 79:1482-1495.

Pedersen, P. 2007. Soybean Growth and Development. https://crops.extension.iastate.edu/ files/article/SoybeanGrowthandDevelopment_0.pdf. Iowa State University Extension and Outreach, Ames, IA.

Ruffo, M. L., Bullock, D. G., and Bollero, G. A. 2004. Soybean yield as affected by biomass and nitrogen uptake of cereal rye in winter cover crop rotations. Agron. J. 96:800-805.

Sarrantonio, M., and Gallandt, E. 2003. The role of cover crops in North American cropping systems. J. Crop Prod. 8:53-74.

Schenck, L., Bakker, M. G., Moorman, T. B., and Kaspar, T. C. 2017. Effects of cover crop presence, cover crop species selection and fungicide seed treatment on corn seedling growth. Renew. Agric. Food Syst. 34:93-102.

Schepers, J. S., Francis, D. D., and Thompson, M. T. 1989. Simultaneous determination of total $\mathrm{C}$, total $\mathrm{N}$, and ${ }^{15} \mathrm{~N}$ on soil and plant material. Commun. Soil Sci. Plant Anal. 20:949-959.

Schutter, M. E., and Dick, R. P. 2002. Microbial community profiles and activities among aggregates of winter fallow and cover-cropped soil. Soil Sci. Soc. Am. J. 66:142-153.
Sinclair, T. R., and Rufty, T. W. 2012. Nitrogen and water resources commonly limit crop yield increases, not necessarily plant genetics. Glob. Food Secur. 1:94-98.

Singer, J. W., Nusser, S. M., and Alf, C. J. 2007. Are cover crops being used in the US corn belt? J. Soil Water Conserv. 62:353-358.

Smiley, R. W., Ogg, A. G., and Cook, R. J. 1992. Influence of glyphosate on Rhizoctonia root rot, growth, and yield of barley. Plant Dis. 76:937-942.

Smith, C. S., Mock, J. J., and Crosbie, T. M. 1982. Variability for morphological and physiological traits associated with barrenness and grain yield in the maize population, Iowa Upright Leaf Synthetic \#11. Crop Sci. 22:828-832.

Snapp, S. S., Swinton, S. M., Labarta, R., Mutch, D., Black, J. R., Leep, R., Nyiraneza, J., and O'Neil, K. 2005. Evaluating cover crops for benefits, costs and performance within cropping system niches. Agron. J. 97:322-332.

Stewart, W. M., Dibb, D. W., Johnston, A. E., and Smyth, T. J. 2005. The contribution of commercial fertilizer nutrients to food production. Agron. J. 97:1-6.

Sturz, A. V., Christie, B. R., and Matheson, B. G. 1998. Associations of bacterial endophyte populations from red clover and potato crops with potential for beneficial allelopathy. Can. J. Microbiol. 44:162-167.

Thelen, K. D., and Leep, R. H. 2002. Integrating a double-cropped winter annual forage into a corn-soybean rotation. Crop Manage. 1. doi: 10.1094/CM-2002 1218-01-RS

Tollenaar, M., Mihajlovic, M., and Vyn, T. J. 1993. Corn growth following cover crops: Influence of cereal cultivar, cereal removal, and nitrogen rate. Agron. J. 85:251-255.

Villamil, M. B., Bollero, G. A., Darmody, R. G., Simmons, F. W., and Bullock, D. G. 2006. No-till corn/soybean systems including winter cover crops. Soil Sci. Soc. Am. J. 70:1936-1944.

Wagger, M. G., and Mengel, D. B. 1993. The role of nonleguminous cover crops in the efficient use of water and nitrogen. Pages 115-127 in: Cropping Strategies for Efficient Use of Water and Nitrogen. ASA Special Publication No. 51. W. L. Hargrove, ed. ASA, CSSA, and SSSA, Madison, WI.

Wen, L., Lee-Marzano, S., Ortiz-Ribbing, L. M., Gruver, J., Hartman, G. L., and Eastburn, D. M. 2017. Suppression of soil borne diseases of soybean with cover crops. Plant Dis. 101:1918-1928. 